\title{
Workshop Penyusunan Program Unggulan OSN di Madrasah Ibtidaiyah Muhammadiyah Tegalampel, Klaten
}

\author{
Muhamad Taufik Hidayat ${ }^{1}$, Nuqthy Faiziyah², Vina Listiawati ${ }^{3}$, \\ Ika Fajar Rini ${ }^{4}$, Surahmat ${ }^{5}$ \\ 1,2, 3, 4, 5 Universitas Muhammadiyah Surakarta
}

\begin{tabular}{l}
\hline Article History \\
\hline Received 25.07 .2018 \\
Received in revised form \\
15.01 .2019 \\
Accepted 21.03.2019 \\
Available online 02.04 .2019
\end{tabular}

\section{ABSTRACT}

THE WORKSHOP OF COMPILATION OF SCIENCE OLYMPIAD LEADING PROGRAM IN MADRASAH IBTIDAIYAH MUHAMMADIYAH TEGALAMPEL, KLATEN. The purpose of this social service activity were to provide knowledge and insights related to the science olympiad (OSN) to the headmaster and teachers of MIM Tegalampel as well as assisted the compilation of work programs and committee of MIM Tegalampel. Materials that provided were OSN, best practices, and compilation of work program and committee. The model used was a workshop model with lecture, demonstration, question and answer and hands-on practice method. Evaluation was done by disseminating information and motivation to participants and product checklists. Generally, participants claimed that the schedule training was appropriate, time sharing (lectures, group discussions, individual assignments, presentations and games) were also perceived positively by participants. Participants were satisfied with the topics presented and perceived that most of the expectations and objectives of the workshop were fulfilled. The evaluation results indicate that the material delivered can be followed well and there was an increase in knowledge and motivation. In addition, the OSN work program and committee have also been arranged quite well.

Keywords: Elementary School, Madrasah Ibtidaiyah, Science Olimpiade. Attribution 4.0 International License, which permits unrestricted use, distribution, and reproduction in any medium, provided the original work is properly cited. ○ 2019 Muhamad Taufik Hidayat, Nuqthy Faiziyah, Vina Listiawati, Ika Fajar Rini, Surahmat.

\section{PENDAHULUAN}

Madrasah Ibtidaiyah Muhammadiyah (MIM) Tegalampel merupakan salah satu Amal Usaha Muhammadiyah di Kecamatan Karangdowo, Kabupaten Klaten yang tengah mempersiapkan diri menjadi salah satu Sekolah Dasar (SD) yang unggul. Meskipun tidak terletak di tengah kota, namun MIM Tegalampel pada tahun-tahun terakhir telah menunjukkan prestasi yang cukup signifikan. Prestasi dari MIM Tegalampel merupakan 
hasil dari komitmen Kepala Madrasah beserta staf pengajar untuk selalu berbenah dan mengembangkan diri. Potensi yang besar dari MIM Tegalampel tersebut perlu dikelola dan dikembangkan secara baik.

Salah satu program unggulan yang cukup baik untuk dikembangkan adalah program Olimpiade Sains Nasional atau OSN. Prestasi siswa-siswi MIM Tegalampel dibandingkan dengan SD di Kecamatan Karangdowo dalam ajang OSN belum begitu menggembirakan. Prestasi tertinggi yang diraih dalam 5 tahun terakhir hanya pernah sekali meraih medali perunggu di tingkat Kabupaten pada tahun 2015. Oleh karenanya perlu upaya pengembangan potensi yang dimiliki siswa secara lebih intensif lagi.

Berdasarkan hasil wawancara dengan Kepala serta staf pengajar MIM Tegalampel, diperoleh beberapa informasi berkaitan dengan belum optimalnya prestasi siswa MIM Tegalampel dalam OSN, diantaranya sebagai berikut: (1) Siswa yang dipilih menjadi peserta OSN biasanya siswa yang memiliki nilai bagus di kelas. Seharusnya sekolah harus mampu mengidentifikasi siswa-siswa mana saja yang mempunyai potensi atau bakat Matematika maupun yang mempunyai kemampuan biasa-biasa saja dalam Matematika. Untuk dapat mengidentifikasi potensi tersebut sangat diperlukan instrumen soal yang tepat. (2) Pembinaan di tingkat sekolah jarang dilakukan, dan kalaupun ada, materinya lebih ditekankan pada apa yang ada di kurikulum yang cenderung berupa soal-soal rutin yang ada di buku paket/buku siswa. (3) Sekolah kesulitan dalam mencari guru yang bersedia untuk ditugaskan membina siswa-siswa yang dianggap berpotensi. Guru-guru beralasan tidak menguasai sains (matematika dan IPA) dengan baik dan juga kesulitan mendapatkan dan mengembangkan materi untuk pembinaan OSN. (4) Partisipasi MIM Tegalampel dalam OSN selain OSN, seperti MOSI (Menuju OSN Indonesia) dan Lomba MIPA (Matematika dan IPA) tingkat SD yang diselenggarakan oleh beberapa institusi masih minim. Padahal akses transportasi dari MIM Tegalampel ke beberapa Universitas di Surakarta maupun Yogyakarta cukup mudah dengan jarak tempuh hanya sekitar 1-2 jam.

Berdasarkan paparan di atas, akar permasalahan belum optimalnya prestasi siswa MIM Tegalampel dalam ajang OSN adalah belum adanya sistem pembinaan yang matang di masing-masing sekolah dalam membina siswa-siswa yang berpotensi. Guru-guru MIM Tegalampel yang notabene adalah guru kelas merasa belum siap dan merasa kesulitan dalam melakukan pembinaan karena penguasaan materi olimpiade yang kurang dan merasa kurang mampu dalam mencari dan mengembangkan materi untuk pembinaan. Apabila kondisi ini diteruskan, ajang OSN yang seharusnya menjadi wahana untuk mengembangkan bakat dan minat siswa di bidang sains, hanya akan menjadi kegiatan rutin yang bersifat formal belaka dan potensi besar yang dimiliki siswa tidak akan berkembang secara optimal. Oleh karenanya perlu upaya peningkatan kemampuan guruguru MIM Tegalampel dalam melakukan pembinaan OSN.

\section{METODE PELAKSANAAN}

Kegiatan pengabdian ini dilaksanakan dalam bentuk workshop, dan diikuti oleh Kepala Sekolah dan 12 guru MIM Tegalampel sebagai mitra program pengabdian. Materi yang diberikan meliputi: (1) OSN, (2) Best Practice, serta (3) Penyusunan Program Kerja dan Kepanitiaan. Metode yang digunakan oleh tim pengabdian masyarakat dalam rangka memecahkan permasalahan yang dihadapi oleh mitra disesuaikan dengan jenis kegiatannya. Rincian metode seperti dicantumkan pada Tabel 1. 
Untuk mengukur keberhasilan kegiatan pengabdian maka diadakan evaluasi. Evaluasi dilakukan dengan cara menyebarkan angket pengetahuan dan motivasi pada peserta, serta penilaian produk. Evaluasi yang digunakan adalah angket pengetahuan dan motivasi serta daftar cek produk.

Tabel 1. Metode Program

\begin{tabular}{lll}
\hline Sesi & Metode & Instrumen Evaluasi \\
\hline OSN Nasional & Ceramah dan tanya jawab & $\begin{array}{l}\text { Angket pengetahuan } \\
\text { dan motivasi }\end{array}$ \\
\hline Best Practice & Ceramah, dan tanya jawab & $\begin{array}{l}\text { Angket pengetahuan } \\
\text { dan motivasi }\end{array}$ \\
\hline $\begin{array}{l}\text { Penyusunan } \\
\begin{array}{l}\text { Program Kerja } \\
\text { dan Kepanitiaan }\end{array}\end{array}$ & $\begin{array}{l}\text { Model workshop dengan metode } \\
\text { ceramah, demonstrasi, tanya jawab } \\
\text { dan praktik langsung. }\end{array}$ & Daftar cek produk \\
\hline
\end{tabular}

\section{HASIL DAN PEMBAHASAN}

Kegiatan pengabdian ini dilakukan melalui beberapa tahapan, yaitu: (1) Mengurus surat ijin pelaksanaan (2) Sosialisasi program kepada sekolah mitra, yaitu MIM Tegalampel (3) Penyusunan materi-materi workshop; (4) pelaksanakan program pengabdian (5) Monitoring program kerja program serta (6) Refleksi program kerja.

Setelah tempat, dan waktu disepakati, kemudian tim pengabdian menyiapkan materi workshop yang meliputi materi pengenalan OSN, best practice serta pembentukkan tim pembina program OSN (kepanitiaan) dan program kerja OSN. Setelah penyusuan materi workshop selesai, kemudian dilakukan pembuatan instrumen evaluasi berupa angket dan daftar cek produk.

Kegiatan pengabdian masyarakat dilaksanakan pada hari rabu, 14 Maret 2018. Lokasi pengabdian bertempat di MIM Tegalampel, Karangdowo, Kabupaten Klaten. Kegiatan pengabdian masyarakat ini dikemas dalam bentuk workshop, yaitu Workshop Penyusunan Program Unggulan OSN MIM Tegalampel. Kegiatan workshop dihadiri oleh guru, kepala sekolah, dan komite sekolah MIM Tegalampel yang jumlah keseluruhan 13 peserta.

Rangkaian kegiatan workshop diawali dengan pembukaan oleh pembawa acara, sambutan-sambutan oleh komite dan kepala MIM Tegalampel, kemudian dibuka sesisesi, meliputi pengenalan OSN Nasional (OSN), best practice, penyusunan program OSN dan Kepanitiaan., serta evaluasi peserta.

\section{Pengenalan Olimpiade Sains Nasional}

Materi yang disampaikan dalam sesi ini adalah pengenalan secara umum tentang OSN, meliputi latar belakang, sejarah singkat, serta tujuannya. OSN pada jenjang SD terdiri dari dua bidang, Matematika dan IPA. Pemateri juga menjelaskan tahapan seleksi yang akan dilalui dalam OSN. Peserta OSN dari MIM Tegalampel akan mengikuti OSN Kecamatan yang diselenggarakan Dinas Pendidikan Kecamatan Karangdowo, OSN Kabupaten yang diselenggarakan Dinas Pendidikan Kabupaten Klaten, OSN Provinsi yang diselenggarakan Dinas Pendidikan Provinsi Jawa Tengah, serta OSN yang diselenggarakan Kementrian Pendidikan dan Kebudayaan. Pemateri juga menyampaikan 
jika MIM Tegalampel mempunyai potensi yang bagus dalam OSN karena delegasi Jawa Tengah hampir selalu mendominasi perolehan medali OSN.

Selanjutnya disampaikan persyaratan peserta dan pendamping OSN tingkat SD bidang IPA. Sebelumnya peserta workshop berpikir jika siswa MIM tidak dapat mengikuti OSN, namun dapat mengikuti Kompetisi Sains Madrasah (KSM). Dipaparkan juga secara lengkap rambu-rambu tes seleksi OSN IPA mulai dari tingkat kecamatan sampai nasional, tim juri, pendanaan, juara dan penghargaan, serta materi bidang IPA. Berikutnya dipaparkan tentang OSN bidang Matematika serta strategi pembinaannya. Pemateri menyampaikan jika strategi pembinaan harus memperhatikan enam hal yang meliputi; organisasi (kepanitiaan), sistem pembinaan, siswa, orang tua serta pendanaan.

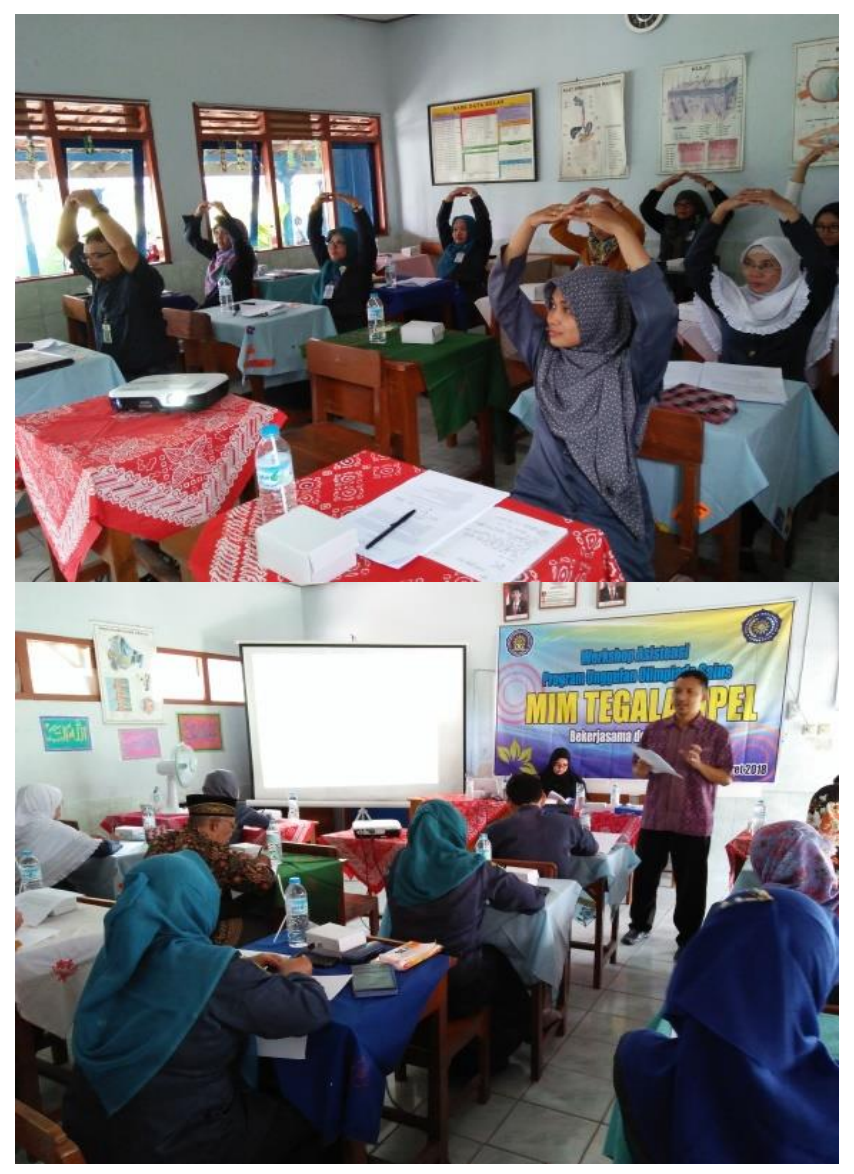

Gambar 1. Materi OSN Nasional

\section{Best Practice}

Pada sesi ini pemateri menyampaikan pengalaman-pengalaman pribadi maupun pihak lain dalam mengikuti OSN maupun menjadi pembina. Pemateri yang juga merupakan mantan peserta OSN tidak hanya bercerita tentang bagaimana pengalaman mempersiapkan dan mengikuti OSN secara akademis, namun juga secara mental. Sebagai contoh bagaimana apresiasi sekolah maupun pembina sangat berpengaruh terhadap keberhasilan peserta OSN. Pemateri juga berbagi metode yang dipakai oleh beberapa sekolah maupun lembaga pembinaan OSN yang telah terbukti efektif dalam mencetak juara-juara OSN. 


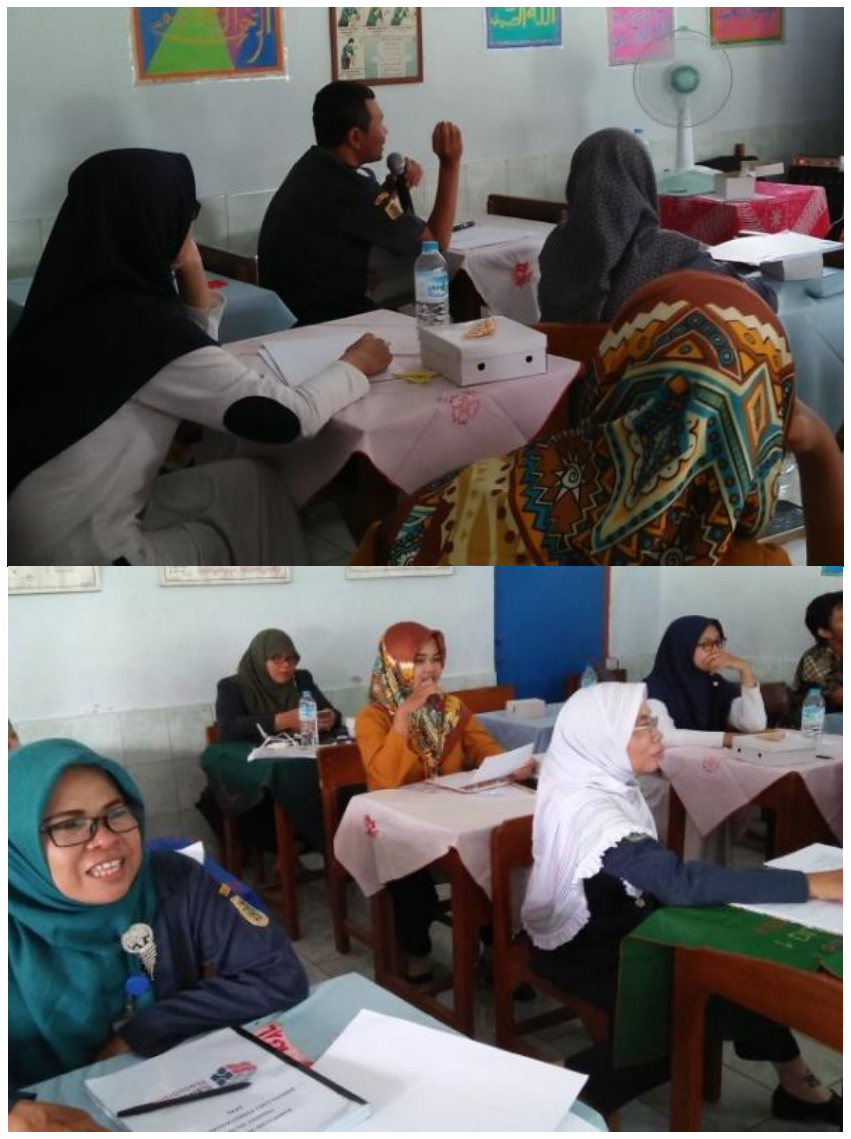

Gambar 2. Materi Best Practice

\section{Penyusunan Program OSN dan Kepanitiaan}

Acara selajutnya yaitu penyusunan program OSN dan kepanitiaan. Peserta dibagi secara berkelompok. Melalui arahan dari pemateri, peserta diarahkan untuk membuat rancangan progam dalam mempersiapkan OSN. Peserta juga dibentuk struktur organisasinya untuk menjadi pembina pada persiapan OSN. Melalui bimbingan dari pemateri, peserta diarahkan untuk mendiskusikan bagian-bagian yang harus disusun dalam proses persiapan OSN sampai tahap evaluasi. Setelah itu secara bergantian perwakilan kelompok melaporkan hasil diskusi. Peserta saling berargumen dan memberikan masukan kepada kelompok lain. Berikut ini paparan rancangan program kerja OSN MIM Tegalampel yang disusun oleh peserta pengabdian.

\section{Tahap Persiapan}

Untuk tahap persiapan, yang pertama akan dilakukan adalah menyeleksi atau melakukan skrining calon peserta OSN yang akan mewakili MIM Tegalampel. Dari hasil diskusi kelompok, pemilihan kandidat akan dilakukan berdasarkan nilai raport Matematika dan IPA kelas III, IV dan V, minat dan bakat kandidat dalam Matematika dan IPA. Tidak kalah penting juga dengan mempertimbangkan hasil tes IQ (Intelegent Quotient) pada saat kelas I. Beberapa strategi seleksi yang bisa dipakai diantaranya adalah metode Elimination and Choice Translation Reality (Damanik, 2015), penerapan Algoritma Analytical Hierarchy Process (Mujilahwati \& Setyati, 2012; Rianti \& Pratama, 2016), metode Simple Additive Weighting (Hutagalung, 2017), menggunakan logika Fuzzy (Karnadi, 2017), metode Topsis (Sukirman, 2014) maupun menerapkan klasifikasi 
berbasis learning vector quantization (LVQ) menggunakan optimasi learning rate (Pujianto, Hariadi, \& Sumpeno, 2013).

Kedua, pemilihan atau skrining calon pembina OSN MIM Tegalampel. Peserta sepakat jika pemilihan calon pembina OSN seharusnya berdasarkan bidang ilmu guru. Sebagai contoh guru yang berlatar belakang pendidikan Matematika akan sangat berpotensi menjadi pembina OSN Matematika. Faktor lain yang mendasari pemilihan calon pembina OSN di MIM Tegalampel adalah kemampuan, komitmen, pengalaman serta tekad. Empat faktor terakhir ini dianggap peserta akan sangat menunjang seorang guru menjadi pembina OSN.

Ketiga, kegiatan pengkajian kurikulum OSN. Kegiatan ini amat vital, karena calon peserta OSN akan mempersiapkan diri dengan efektif dan efisien jika kurikulum OSN yang dipakai MIM Tegalampel sesuai dengan kurikulum OSN yang akan dilombakan. Peserta sepakat untuk menyusun kurikulum tiga materi OSN yaitu Matematika, IPA dan Bahasa Inggris. Materi Matematika akan berfokus pada materi: bilangan, aritmatika, geometri, statistika, data dan pengukuran, serta kombinatorit. Materi IPA meliputi materi: metode ilmiah, klasifikasi, proses mekanisme makhluk, interaksi, isu-isu umum IPA, mekanika, wujud benda, listrik, magnet, gelombang, optik, suhu dan panas, energi, atom, bumi, dan tata surya. Untuk materi Bahasa Inggris meliputi vocabulary dan tenses.

Keempat, kegiatan kajian dan pengadaan referensi materi OSN. Peserta sepakat untuk membuat bank soal dengan mengumpulkannya dari browsing di internet, mencari buku-buku OSN serta meminta file dari sekolah lainnya. Tim pengabdian memberikan beberapa website yang dikenal luas sebagai bank soal OSN yang cukup baik. Bank soal yang disusun tersebut kemudian ditelaah apakah sesuai dengan kurikulum OSN yang terbaru atau tidak.

Kegiatan selanjutnya atau kelima adalah kegiatan pengkajian dan pengadaan laboratorium Matematika dan IPA. Laboratorium tersebut sangat penting karena dalam soal OSN ada yang berupa praktik. Calon peserta OSN yang terbiasa melakukan praktik dengan alat-alat praktikum akan lebih percaya diri dalam menjawab soal. Kendala pengadaan laboratorium yang cukup mahal disikapi peserta dengan mencetuskan laboratorium alam serta pengadaan alat-alat hasil kreasi sendiri.

Keenam, program peningkatan motivasi siswa. Beberapa kegiatan yang dicetuskan oleh para peserta pengabdian adalah dengan membuat kata-kata penyemangat atau motivasi, pemberian hadiah, serta pengenalan peserta OSN pada saat upacara bendera. Selain itu, pihak MIM Tegalampel juga akan mengadakan kegiatan pemutaran film secara berkala yang akan mendorong motivasi dari siswa MIM Tegalampel untuk berjuang dalam OSN. Beberapa film yang dicetuskan adalah film "Semesta Mendukung", "Laskar pelangi", “Denias", serta film dari Iran yang berjudul "Children of Heaven (Iran)". Filmfilm yang mengisahkan anak-anak pejuang tersebut diharapkan akan menginspirasi siswa MIM Tegalampel dalam mengikuti OSN. Hasil penelitian (Hayati, 2016; Rosalinda \& Aminullah, 2017) menunjukkan film-film motivasi efektif meningkatkan motivasi berprestasi.

Ketujuh dan juga tidak kalah penting adalah program peningkatan motivasi guru. Peserta meyakini jika guru MIM Tegalampel sebagai calon pembina OSN akan termotivasi dengan mengikuti pelatihan pembina OSN. Selanjutnya apresiasi dari pihak MIM Tegalampel pada pembina OSN juga akan menentukan motivasi guru. 
Kedelapan berkaitan dengan reward atau hadiah Dari hasil diskusi peserta, beberapa jenis hadiah yang direkomendasikan adalah berupa uang saku serta alat tulis. Peserta meyakini walaupun nilai dari uang saku maupun alat tulis itu kecil, namun jika diberikan dengan penuh penghormatan, maka akan berefek sangat besar pada motivasi siswa. Uang saku untuk Pembina juga dianggap cukup penting.

Terakhir, terkait dengan proses pembinaan siswa. Dalam waktu dekat akan disusun jadwal pembinaan rutin pada kandidat peserta OSN. Pembinaan akan dilakukan dengan berbagai waktu dan kesempatan. Jam ke 0 (sebelum jam sekolah) maupun jam pasca sekolah dianggap menarik untuk dikombinasikan.

\section{Tahap Pelaksanaan}

Untuk tahap pelaksanaan, kegiatan pertama yang dilakukan adalah memilih atau menagadakan skrining kompetisi yang menunjang siswa MIM Tegalampel dalam mengikuti OSN. Skrining kompetisi dapat dilakukan dengan mencari informasi di berbagai media cetak maupun reklame. Selain itu, berselancar di website juga sangat penting dalam menggali informasi lomba-lomba yang akan diadakan. Kompetisi yang dipilih diutamakan yang paling menguntungkan dan memungkinkan bagi kepentingan siswa dan MIM Tegalampel. Seperti halnya memilih lokasi yang relatif dekat, biaya pendaftaran yang murah, maupun yang paling berpotensi untuk mendapatkan juara.

Kedua, Pembinaan sepanjang kompetisi. Ada banyak ide yang disampaikan peserta dalam program ini. Diantaranya dalah dengan menerapkan kegiatan karantina jam ke 0 , memberikan motivasi dan penguatan mental pada siswa, memecahkan bank soal, membandingkan soal-soal OSN, serta dibina untuk menentukan target soal yang sudah bisa dikerjakan. Disamping itu siswa juga akan diajarkan untuk mencintai sains (matematika dan IPA) sert untuk tidak cepat puas dengan hasil yang telah dicapai. Hal yang penting dan tidak boleh terlupakan adalah meminta restu kepada orang tua siswa serta berdoa.

Ketiga, pembinaan kurikuler sepanjang kompetisi. Hal ini penting dilakukan karena siswa peserta OSN tidak boleh melupakan bahwa ada materi lain selain IPA atau Matematika yang harus dipelajari sebagai siswa. Untuk itu MIM Tegalampel juga perlu memikirkan solusi dari permasalahan ini. Beberapa kegiatan yang digagas peserta adalah dengan memberikan jam tambahan pada siswa peserta OSN, memberikan materi yang tertinggal beserta metode khusus untuk menguasai materi yang tertinggal.

Terakhir terkait dengan pembiayaan kompetisi selama pelaksanaan OSN berlangsung. Sumber dana yang utama tentu saja dari sekolah, berupa dana bantuan operasional sekolah (BOS) MIM Tegalampel. MIM Tegalampel juga dapat mencari donator potensial baik dari wali siswa, tokoh masyarakat, maupun pihak lain. Bisa juga dengan mencari sponsor dari pihak pemberi sponsor seperti penerbit buku, bimbingan belajar dan sebagainya.

\section{Tahap Evaluasi}

Pertama, melakukan evaluasi materi-materi prioritas. Hal ini sangat mungkin dilakukan setelah beberapa kali mengikuti OSN. Materi-materi yang strategis harus lebih diperhatikan, sementara materi yang jarang muncul dieliminasi. Evaluasi juga dapat ditindaklanjuti dengan memperbanyak koleksi bank soal, membandingkan soal-soal dari bank soal serta mengembangkan materi OSN untuk pembinaan di MIM Tegalampel. 
Kedua, evaluasi strategi belajar yang telah diterapkan. Peserta merumuskan beberapa evaluasi yang bisa dilakukan seperti halnya penjadwalan jangka pendek maupun jangka panjang. Metode pembelajaran yang dianggap kurang sesuai dengan peserta juga penting dievaluasi, direvisi atau menindaklanjuti kelemahan metode tersebut dengan memberikan materi tambahan di luar jam pelajaran (drill)

Ketiga, evaluasi jenis kompetisi yang telah diikuti. Beberapa peserta memiliki pengalaman terkait mendampingi siswa MIM Tegalampel dalam sebuah kompetisi. Ada kalanya terjadi hal-hal yang tidak diinginkan seperti ketakutan dan ragu untuk berangkat saat hari $\mathrm{H}$, mabuk saat perjalanan, minder saat di tempat perlombaan dan sebagainya. Oleh karena itu peserta mencetuskan kegiatan pembinaan mental anak seperti bernyanyi di dalam kelas maupun saat upacara. Selain itu dilakukan pemilihan jenis lomba berdasarkan kemampuan anak atau jenjang usia siswa.

Keempat terkait evaluasi pembiayaan. Adanya target yang meleset diyakini oleh peserta salah satunya karena tidak totalnya Pembina. Oleh karena itu peserta menyarankan adanya review terkait hadiah pada siswa atau Pembina.

Kegiatan terakhir pada tahap ini adalah rencana revisi dan pengembangan program. Kegiatan ini tentu saja dilaksanakan setelah proses evaluasi. Beberapa yang direkomendasikan untuk dilakukan adalah penjadwalan ulang program, merevisi dan mengembangkan metode pembelajaran, serta memberikan materi tambahan dan drill.

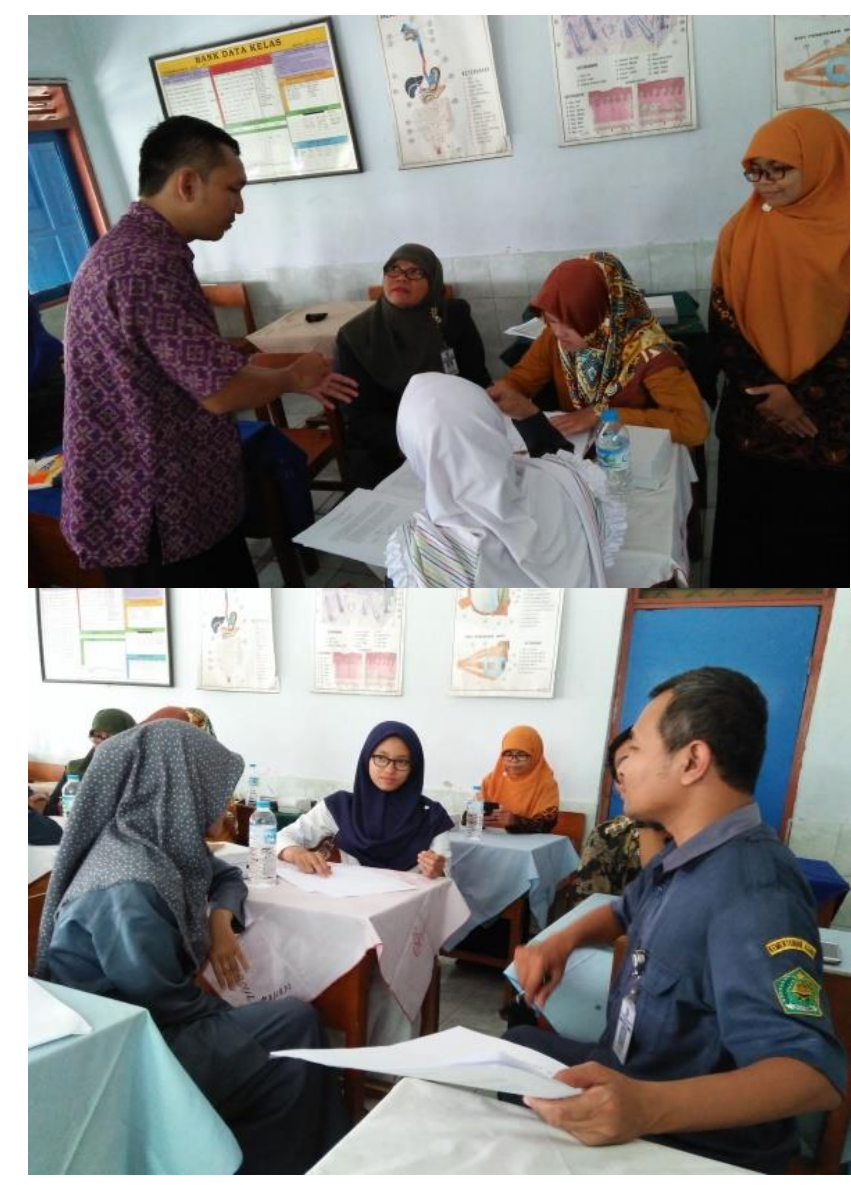

Gambar 3. Penyusunan Program Kerja OSN dan Kepanitiaan 


\section{Evaluasi Peserta}

Dari hasil angket pengetahuan diketahui bahwa secara umum peserta cukup baik dalam memahami hakikat OSN. Peserta memahami jika kegiatan OSN mampu meningkatkan nalar, mental serta jiwa kompetitif siswa. Hal yang perlu diperhatikan dalam OSN IPA adalah seleksi peserta, pembina, organisasi, dan pembiayaan sedangkan dalam OSN Matematika adalah latihan soal dan strategi. Sementara itu berdasarkan angket motivasi diketahui bahwa pada umumnya peserta merasa MIM Tegalampel sudah tepat memilih OSN sebagai program unggulan, merasa mampu membimbing siswa dalam OSN serta yakin jika siswa MIM Tegalampel mampu meraih prestasi yang baik dalam OSN. Program OSN MIM Tegalampel. Terakhir, terkait produk workshop sudah tercapai yaitu berupa Program Kerja OSN serta kepanitiaan. Hanya saja program kerja belum dilengkapi tanggal pelaksanaan.

\section{SIMPULAN}

Berdasarkan hasil pelaksanaan workshop penyusunan program unggulan OSN MIM Tegalampel, maka dapat disimpulkan bahwa secara umum peserta menganggap penjadwalan workshop sudah tepat, pembagian waktu (ceramah, diskusi kelompok, tugas individu, presentasi dan permainan) juga dianggap sudah sesuai, keseimbangan antara teori dan praktik juga dipersepsikan oleh peserta secara positif. Peserta merasa puas dengan topik-topik yang disajikan serta menganggap sebagian besar harapan dan tujuan dari workshop sudah terpenuhi.

Kesan yang didapatkan oleh peserta workshop adalah workshopnya menarik, bermanfaat, menyenangkan, memberi motivasi dan semangat, menambah ilmu dan wawasan, menemukan ide baru terkait OSN, menjadi lebih tahu tentang OSN serta tertantang untuk melaksanakan. Saran dari peserta workshop adalah; workshop terus dilanjutkan, memperbaiki pengalokasian waktu, mengorganisasikan program kerja sesuai kompetensi guru, penambahan waktu workshop, lebih terperinci dalam penyampaian materi.

Hasil evaluasi menunjukkan bahwa materi yang disampaikan dapat diikuti peserta dengan baik serta terjadi peningkatan pengetahuan dan motivasi. Selain itu program kerja dan kepanitian OSN juga sudah tersusun dengan cukup baik.

\section{REFERENSI}

Damanik, O. O. (2015). Sistem pendukung keputusan pemilihan siswa peserta olimpiade SMA Negeri 1 Lubuk Pakam Deliserdang menerapkan metode elimination and choice translation reality (Electre). Pelita Informatika Budi Darma, 9(1), 145-153.

Hayati, M. (2016). Efektivitas penggunaan media film "Tanah surga katanya" untuk Peningkatan motivasi dan prestasi belajar. E-CIVICS, 5(8), 127-140.

Hutagalung, D. M. (2017). Analisis pemilihan calon peserta olimpiade sains dengan metode simple additive weighting (SAW). Mahajana Informasi, 2(2), 20-30. 
Karnadi, V. (2017). Sistem Pendukung keputusan pemilihan siswa peserta olimpiade sains menggunakan logika fuzzy (Studi kasus: SMA Negeri 2 Sungai Penuh). JIPSI, 4, 130152.

Mujilahwati, S., \& Setyati, E. (2012). Penerapan algoritma AHP (Analytical Hierarchy Process) untuk pengambilan keputusan dalam seleksi calon peserta olimpiade sains nasional bidang matematika. Jurnal Ilmiah Teknologi Informasi Asia, 6(2), 53-59.

Pujianto, W. H., Hariadi, M., \& Sumpeno, S. (2013). Klasifikasi berbasis LVQ menggunakan optimasi learning rate untuk memilih siswa peserta OSN. In Prosiding Seminar Nasional Manajemen Teknologi XVII. Surabaya: Institut Teknologi sepuluh November (ITS). Retrieved from http://mmt.its.ac.id/download/SEMNAS/SEMNAS XVII/MTI/15. Wahyu Hadi Pujianto.pdf

Rianti, E., \& Pratama, R. N. (2016). Designing application decision support system for science olympics participants election in SMPN Sijunjung using analytical hierarchy process methods. Jurnal Sains dan Informatika, 2(2), 49-60.

Rosalinda, I., \& Aminullah, A. R. (2017). Efektivitas film bertema motivasi terhadap peningkatan motivasi berprestasi. JPPP: Jurnal Penelitian dan Pengukuran Psikologi, 6(2). doi: 10.21009/JPPP.062.06

Sukirman. (2014). Sistem pendukung keputusan menggunakan metode topsis untuk pemilihan siswa dalam mengikuti olimpiade sains di SMAN 1 Palopo. d'ComPutarE, $4(1), 8-21$. 